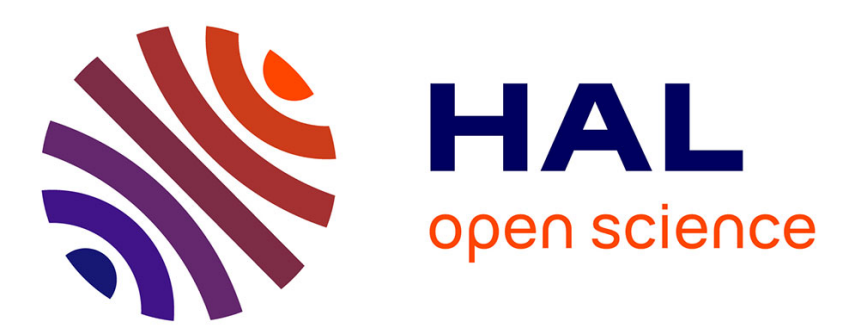

\title{
Site context and the spatial organization of a late Holocene coastal hunter-gatherer campsite in North-Central Chile, South America
}

César Méndez, Matthieu Carré, Antonio Maldonado, Roxana Seguel, Donald Jackson

\section{To cite this version:}

César Méndez, Matthieu Carré, Antonio Maldonado, Roxana Seguel, Donald Jackson. Site context and the spatial organization of a late Holocene coastal hunter-gatherer campsite in North-Central Chile, South America. Latin American Antiquity, 2020, 31 (4), pp.765-779. 10.1017/laq.2020.60 . hal-03145726

\section{HAL Id: hal-03145726 \\ https://hal.science/hal-03145726}

Submitted on 29 Nov 2021

HAL is a multi-disciplinary open access archive for the deposit and dissemination of scientific research documents, whether they are published or not. The documents may come from teaching and research institutions in France or abroad, or from public or private research centers.
L'archive ouverte pluridisciplinaire HAL, est destinée au dépôt et à la diffusion de documents scientifiques de niveau recherche, publiés ou non, émanant des établissements d'enseignement et de recherche français ou étrangers, des laboratoires publics ou privés. 


\section{SITE CONTEXT AND THE SPATIAL ORGANIZATION OF A LATE HOLOCENE COASTAL HUNTER-GATHERER CAMPSITE FROM NORTH-CENTRAL CHILE, SOUTH AMERICA}

César Méndez, Matthieu Carré, Antonio Maldonado, Roxana Seguel and Donald Jackson†

DO NOT CITE IN ANY CONTEXT WITHOUT PERMISSION OF THE AUTHORS

César Méndez Centro de Investigación en Ecosistemas de la Patagonia, José de Moraleda 16, Coyhaique, Chile (cesar.mendez@ ciep.cl, corresponding author) Matthieu Carré LOCEAN, UMR CNRS-IRD-MNHN-Sorbonne Universités (UPMC), 4 Place Jussieu, Paris, France and CIDIS-Facultad de Ciencias y Filosofía-LID, Universidad Peruana Cayetano Heredia, Av. Honorio Delgado 430, Lima, Perú Antonio Maldonado Centro de Estudios Avanzados en Zonas Áridas and Instituto de Investigación Multidisciplinario en Ciencia y Tecnología, Universidad de La Serena, Raúl Bitrán 1305, La Serena, Chile, and Departamento de Biología Marina, Universidad Católica del Norte, Larrondo, 1281, Coquimbo, Chile.

Roxana Seguel Centro Nacional de Conservación y Restauración, Servicio Nacional del Patrimonio Cultural, Recoleta 683, Santiago, Chile 
Donald Jackson Departamento de Antropología, Facultad de Ciencias Sociales, Universidad de Chile, Ignacio Carrera Pinto 1045, Ñuñoa, Santiago, Chile 
The site context of a late Holocene shell midden on the coast of Los Vilos in north-central Chile ( $31^{\circ} 51^{\prime} \mathrm{S}$, South America) is explored to understand the spatial organization of briefterm small-sized hunter-gatherer campsites. The Dunas de Agua Amarilla (LV 007) site is a small archeological locale comprising fourteen individual surf clam refuse deposits. Extensive stratigraphic excavations of the shell middens and areas free of residue allowed interpretation of potential activity areas bounded by hearths and the shell middens and a possible dwelling space. We present data on shell midden composition and the spatial distribution of site features to discuss aspects of activity planning and campsite organization. Late Holocene campsites in the area correspond to brief occupational events framed within littoral residential mobility in which predictable coastal resources became a staple for groups residing and circulating over long periods in the area. The intrasite characteristics discussed herein shed light on the organizational dynamics of dwelling and activity spaces of coastal hunter-gatherers of the South Pacific.

Keywords: shell middens, intrasite spatial organization, coastal hunter-gatherers, northcentral Chile, late Holocene 
Se explora el contexto de sitio de un conchal del Holoceno tardío de la costa de Los Vilos en el centro-norte de Chile (31 $51^{\circ}$ 'S, Sudamérica) para comprender la organización espacial de campamentos de cazadores recolectores pequeños y de corta duración. El sitio Dunas de Agua Amarilla (LV 007) es una pequeña locación arqueológica que incluye catorce depósitos individuales del descarte de machas. Excavaciones estratigráficas extensivas de los conchales y de sectores libres de desechos permitieron la interpretación de potenciales áreas de actividad limitadas por fogones y conchales, además de un posible espacio de habitación. Presentamos datos de la composición de los conchales y de la distribución espacial de los rasgos del sitio para discutir aspectos del plan de actividades y de la organización del campamento. Los campamentos del Holoceno tardío en el área corresponden a breves eventos ocupacionales enmarcados en una movilidad residencial a lo largo del litoral en donde los recursos costeros predecibles se transformaron en alimentos de primera necesidad para los grupos que residieron y circularon durante largos periodos en el área. Las características intra-sitio discutidas aquí ilustran las dinámicas organizacionales de los espacios de habitación y actividades de los cazadores recolectores costeros del Pacífico Sur.

Palabras clave: conchales, organización espacial intra-sitio, cazadores recolectores costeros, centro-norte de Chile, Holoceno tardío. 
Shell middens are archeological sites that result from the accumulation of shellfish and other coastal refuse produced by the harvesting of marine resources (Claassen 1998; Stein 1992; Waselkov 1987). The study of these sites has focused mainly on studying the frequency and variability of the invertebrate species present in their zooarcheological assemblages to understand their economic role in societies and on climate change (Jerardino 1997; Koike 1986; Sandweiss 1996). Other equally relevant groups of studies have focused on formation processes, considering, for instance, shells as sedimentary particles within a geoarcheological perspective (Erlandson and Moss 2001; Favier-Dubois and Borella 2007; Mason et al. 1998; Stein 1992). However, a third area of interest has focused on the architectural dimension of mound building by interpreting their territorial significance (DeBlasis et al. 2007; Gamble 2017; Méndez and Nuevo-Delaunay 2020). The high frequency of shell refuse in these sites has often precluded the intrasite spatial analyses generally requiring the excavation of large areas, thus placing special challenges on sampling (Jerardino 2016; Niemeyer and Schiappacasse 1969; Thompson et al. 2016). However, under particular circumstances, the spatial organization of shell middens and heaps may be informative regarding the way in which activities were structured within a site. Sites such as Quebrada Jaguay (QJ280) and Quebrada de los Burros along the central Andean coast of South America constitute examples in which the distribution of shell remains and other features has allowed identifying activity areas and/or dwelling spaces of hunter-gatherers (Lavallée and Julien 2012; Sandweiss et al. 1999; Sandweiss et al. 1998). Distinguishing activity areas is key in the understanding of the spatial organization of a settlement. As such, the high visibility and preservation of shell middens may be regarded as ephemeral architectural features useful for identifying aspects of the spatial organization of residential campsites. This paper presents a case study in which the 
structural characteristics and location of shell middens, hearths, activity areas, void spaces and other features are used to interpret site planning. The Dunas de Agua Amarilla (LV 007) site is a small shell midden in the Los Vilos area of Central Chile (Figure 1A), where preferential harvesting and processing of macha (Mesodesma docnacium), a surf clam, occurred over a series of brief-span occupations at ca. 3000-3500 cal BP. The results presented herein have methodological implications for understanding sites that otherwise do not show highly visible or preserved structures and organic remains. From this perspective, the main originality of this study is not only to deem middens and features as deposits bearing cultural information but also the consideration of "empty" spaces, seldom understood as sources informative of the spatial organization.

More than 400 archaeological sites of diverse characteristics have been recorded between $31^{\circ} 45^{\prime}$ and $32^{\circ} \mathrm{S}$, the coastal area around Los Vilos town (Méndez and Nuevo-Delaunay 2020). This remarkable site density contrasts with equivalent littoral extensions to the north or south of this area. The marine richness in this protected bay area attracted coastal foragers repeatedly across the Holocene (Figure 1B). Hence, the main archaeological features are shell middens of variable sizes and degrees of redundancy (Jackson et al. 1995). The occupation of this coastal strip took many shapes throughout this period as indicated by changes in invertebrate selectivity, procuring behaviors, settlement location and refuse treatment. The first colonizers with a coastal economy were established by 12,000 cal BP in settlement clusters at key locations that granted an extensive littoral provision (Méndez and Nuevo-Delaunay 2020). The advent of major regional climatic changes, of which moisture reduction was the most prominent, came with a diminishment in shellfishing (less visible and smaller middens) by 9,700 cal BP at first, followed by an apparent abandonment of these practices by 8,300 cal BP (Ballester et al. 2012; Jackson et 
al. 2005; Maldonado and Villagrán 2006). A resurgence of shellfish gathering occurred at 7,600 cal BP, when central-place campsites were used to organize the provisioning of a wide variety of resources, including marine and terrestrial mammals and fish (Jackson 2004). Most notable, by this time, the largest available specimens of loco (Concholepas concholepas), the highest meat yielding invertebrate, were field processed for reducing shell weight, thus producing large shell midden deposits close to the shore (Jackson and Méndez 2005; Jackson et al. 2004). The single most marked change in the interaction between humans and shellfish came with the collection of a broadest diversity in intertidal invertebrate ecosystems by 5,300 cal BP (Méndez and Jackson 2006). This change came alongside a higher residential site frequency as suggested by dense, organic and fragmented shellfish-rich stratigraphic layers topped upon most previously occupied sites, hence a residential mobility pattern occurring along the coast has been proposed for this period (Méndez and Jackson 2004). This prominent role of coastal ecosystems probably lasted until 2,300 cal BP, given that the last two millennia came with variable strategies of coastal use, but with a dominant occupation of inland spaces, better suited for horticulture and animal husbandry (Gómez and Pacheco 2016; Massone and Jackson 1994; Seguel et al. 1994; Troncoso et al. 2009).

\section{The study area and present/past environmental conditions}

The study area is located $6 \mathrm{~km}$ north of the town of Los Vilos on the coast of northcentral Chile (31 54 ' S; Figure 1). This area lays in the transition between the Semiarid and Mediterranean climates. It is characterized by long and dry summers with a rainy season concentrated during winter due to the permanent presence of the South Pacific Subtropical 
Anticyclone seasonally blocking the westerly wind belt (Garreaud et al. 2009). This area is highly sensitive to the interannual variations associated with the El Niño Southern Oscillation (ENSO) system, which brings above average warm and humid atmospheric conditions during El Niño years, whereas cold and dry conditions prevail during La Niña years (Montecinos and Aceituno 2003). Plant communities include Asteraceae-dominated shrubland extending across the coastal plains, whereas sclerophyll forests occur in deep gullies (Luebert and Pliscoff 2006).

Local pollen records from coastal swamp forests indicate climatic variability during the Holocene resulting from changes in the position and strength of the South Pacific Subtropical Anticyclone (Maldonado and Villagrán 2002, 2006). Relatively humid conditions during the Pleistocene-Holocene transition were followed by an extremely arid phase between 8200-6200 cal BP (Maldonado et al. 2010; Maldonado and Villagrán 2006). An increase in swamp forest taxa indicates a gradual increase in moisture, peaking at 4200 cal BP (Maldonado and Villagrán 2002, 2006), which agrees with a wetter late Holocene as indicated by broader records (Maldonado et al. 2016). Conditions during the late Holocene fluctuated with less magnitude, showing a trend to relatively drier conditions after $3800 \mathrm{cal}$ $\mathrm{BP}$ and peaking around $2700 \mathrm{cal} \mathrm{BP}$, and after that, a gradual trend to wetter conditions towards 2000 cal BP (Maldonado and Villagrán 2002, 2006). The last 2000 years appear as the most humid period of the Holocene at this latitude, however with minor variations (Maldonado et al 2016), in concordance with highest ENSO activity recorded (Rein et al 2005).

The studied site (LV 007; 31 ${ }^{\circ} 51^{\prime 2} 20^{\prime \prime} \mathrm{S} ; 7^{\circ} 29^{\prime} 50^{\prime \prime} \mathrm{W}$; $40 \mathrm{~m}$ asl) is located on an active dune field known as Agua Amarilla north of Conchalí creek. Dune crests indicate a dominant SW wind $\left(200^{\circ}\right)$ direction. Dunes may have been formed as early as $30,000-$ 
16,500 cal BP judging from radiocarbon dates on associated deposits in the wider area (Méndez et al. 2019; Ortega et al. 2012). The site lies at the center of a deflated depression that offered protection from prevailing winds (Figure 2a). Archeological material occurs over an area of approximately $1,300 \mathrm{~m}^{2}$. One hundred meters to the $\mathrm{NW}$, the Malpaso ravine provides a semipermanent drinkable water supply (Figure 2b), whereas only $1.2 \mathrm{~km}$ to the west, the coast generates abundant, permanent and varied marine biodiversity (Figure 2c).

Analyses of oxygen stable isotopes of $\delta^{18} \mathrm{O}$ on Mesodesma donacium shells obtained from the site, compared with modern samples from the coast at La Serena $\left(\sim 30^{\circ} \mathrm{S}\right)$ and Pullalli $\left(\sim 33^{\circ} \mathrm{S}\right)$, allow us to evaluate changes in sea surface temperatures during the site occupation (Figure 3) (Carré et al. 2005). Positive $\delta^{18} \mathrm{O}$ values of shell samples from 2006 obtained in La Serena (200 km north of Los Vilos) are indicative of relatively dry and cool conditions. Conversely, the negative $\delta^{18} \mathrm{O}$ values of the shell sample from Pullalli harvested in December 1983 indicate warmer and wetter conditions experienced during the 1982-1983 El Niño event. The $\delta^{18} \mathrm{O}$ values from archeological samples collected in shell midden \#4 at LV 007 are close in range to those recorded at La Serena, suggesting conditions were similar to modern normal conditions at $\sim 30^{\circ} \mathrm{S}$. Lower $\delta^{18} \mathrm{O}$ values in shell midden \#11 suggest slightly warmer environmental conditions during the deposition of this occupational event. Assuming a constant isotopic composition of the seawater, the temperature would be $\sim 1^{\circ} \mathrm{C}$ warmer at that time. Shells from LV 007 also recorded lower seasonal amplitude than the modern samples, which may suggest less seasonal variability in the sea temperature or a different precipitation distribution across the year. 


\section{Methods}

The study of the Dunas de Agua Amarilla (LV 007) site was approached from a spatial perspective; hence, its extension, limits and the distribution of visible surface features, primarily shell middens, were recorded. Areas without evident remains of cultural deposition were also considered to fully understand the spatial organization of the site. Both types of areas were included in the excavation plan. Stratigraphic excavations covered 83 $\mathrm{m}^{2}$ and were organized in trenches (Figure 2d) that included continuous areas to provide an ample perspective for understanding the spatial extension of middens and other archeological features (Table 1). These also sought revealing empty spaces as a way of detecting the subsurface limits of areas for presumed activities.

Additionally, one $\mathrm{m}^{2}$ units were excavated on eight of the 14 visible shell middens to define midden stratigraphy, to characterize and quantify their malacological composition and to assess the superposition of individual depositional events. Other material remains, albeit their minor representation, were used for the overall characterization of assemblages representing site activities and preferential subsistence choices. Malacological quantification (MNI) followed key indicators based on local collections at the level of species and subspecies. Mesodesma donacium, the most abundantly represented species, was quantified based on valve laterality.

The surface distribution of 14 small shell middens and lithic debris concentrations, contrasting with areas devoid of archaeological material, suggestive of non-refuse spaces, show some degree of site structure. These hypothetically "clean" areas are the locations where dwelling spaces would be expected, though not directly visible. Excavations 
distributed across the site recorded an upper single stratigraphic unit composed of sands, with subunits distinguishable by grain size, color, stratification, organic matter content and the remains of invertebrates. The chronology of the anthropogenic deposition at LV 007 is constrained by two radiocarbon dates and one thermoluminescence date measured on a firecracked rock. Radiocarbon dates were calibrated with Calib 4.0 (Stuiver et al. 2018) using ShCal 13 (Hogg et al. 2013) and by applying a local reservoir correction $\Delta \mathrm{R}=165 \pm 107$ to the marine sample (Carré et al. 2016). Calibrated dates are reported as $2 \sigma$ intervals.

\section{Results}

The Shell Middens: Formal Attributes and Composition

The site is constituted by fourteen small-sized shell middens, mainly circular in shape resulting from the processing of mollusks gathered in the close intertidal area (Table 2). Diameters of this refuse concentration range between $4.9 \mathrm{~m}$ and $1.2 \mathrm{~m}$, and the thickness of the deposits range between $20 \mathrm{~cm}$ and $2 \mathrm{~cm}$.

A total of 24 mollusk species are represented in the sampled middens (Supplemental Table 1). The best represented species is the Mesodesma donacium, which comprises $81 \%$ of the cumulative evidence at the site (minimum number of individuals, MNI; average per midden $=72.9 \%$; sd = 27.4; Figure 4). In the four largest sampled shell middens, machas represent more than $90 \%$ of the MNI. This bivalve occurs in beaches with a sandy substrate, such as the one located 1,200 m west of the site. The difference between the right and left valves within the samples is $<1 \%$, which indicates that complete individuals were 
transported to the site. Shannon-Weiner diversity index values for each sampled midden range from 0.96 (very diverse) to 0.05 (very homogeneous) (Supplemental Table 1). The second most represented mollusk is the abalone-type Concholepas concholepas, a highbiomass gastropod occurring in rocky intertidal to subtidal zones also available $\sim 1.2 \mathrm{~km}$ from the site. The Fissurella genus represents $3.95 \%$ of the collected mollusks. One midden (\#8) showed a high representation of yet another rocky gastropod, the small-sized white snail Acanthina monodon. Other species occur at frequencies less than $2 \%$ and did not contribute substantially to the gathering choices represented by this assemblage.

Other marine invertebrates, such as sea urchins (Loxechinus albus) and crustaceans, are represented by fragments and may reflect opportunistic gathering. Fish bone remains (NISP 128) represent five species - Sebastes capensis, Thirsistes atun, Trachurus symmetricus, Cilus gilberti and Scartichthys viridis - and comprise seven individuals (Supplemental Table 2). These were all recorded in shell middens \#3 and \#5. The presence of a right mandible of a camelid, most likely the wild guanaco (Lama guanicoe) in shell midden \#8, occurs in the absence of any other skeletal parts, suggesting its transport from elsewhere. Finally, some unidentified carbonized seeds were found in shell middens \#3, \#4 and \#8.

The evidence of lithic material from the shell middens is minimal, and in the great majority of cases, there is debitage from the lithic reduction of locally procured toolstones. The presence of at least one small lithic weight suggests fishing with hook and line technology.

The intensive gathering of machas was probably due to their great abundance, high predictability and ease of collection in the area close to the site. Intensive and preferential exploitation of this species, albeit the availability of higher diversity, as indicated by other 
sampled sites in the environs, suggests that it was processed possibly for consumption elsewhere (Jackson et al. 1995; Méndez 2002; Méndez and Nuevo-Delaunay 2020). Considering the excavated volume, a gross estimate of the total number of specimens in the site is c. 8,200 individuals. Although this species has a relatively low biomass, it is the easiest to collect, being even potentially procured by nonspecialists and children. Its edible part is relatively simply to smoke-dry for preservation. It is most likely that each shell midden corresponds to a unique harvest event. However, larger middens, namely \#3 and \#11, potentially represent either more individuals involved in the activity or more than a single event deposited faster than sedimentation rate.

\section{Features: Hearths and Distinctive Surfaces}

All hearths recorded are simple and small fireplaces, either flat features laying directly on the sand or dug only a few centimeters (Table 3); thus, they bear no distinctive structure (Figure 2e). Their diameters range from 75 to $22 \mathrm{~cm}$, and their shapes are highly variable. Only hearth \#I showed a tenuous structure suggestive of a more prolonged use. In three cases, hearths were associated with shell remains, including burnt specimens of Concholepas concholepas. Nine out of the eleven hearths (\#III-XI) were located towards the periphery of the archeological distribution to the south and to the east of the site. Hearth \#I and \#II were the only ones located at the center of the site and were associated with a distinctive surface and shell midden \#1, respectively.

The excavation of trench \#4, located towards the west of the site, on an area devoid of superficial evidence, revealed the presence of a distinctive 1-3 mm thick buried surface. Higher compaction and darker color evidenced a continuous surface forming a minor 
depression, which reached a maximum depth of $30 \mathrm{~cm}$ at the center of the trench, which gradually diminished towards the west and east (Figure 5a). The profile of this distinctive surface suggests a slightly excavated area along a $4.25 \mathrm{~m}$ axis. Additionally, the N-S profile of this trench showed an inclined feature at the base of the surface, resembling a buried post mold (Figure 5b). A few charcoal particles, small fish bones, two flakes, one pebble stone and fire-cracked rocks, possibly resulting from an undetermined combustion structure, were recorded on this surface. One of these fire-cracked rocks yielded a thermoluminescence age of $2550 \pm 200 \mathrm{BP}$ (UCTL-1706). Adjacent excavation trenches also produced fire-cracked rocks, one core, a hammerstone, and a flake, which suggest minor lithic knapping close to this area.

This distinctive surface has been preliminarily interpreted as the occupational floor of a dwelling space. It must have been a light organic construction using local perishable fibers, such as those from aquatic plants of local availability. These light short-duration dwellings are consistent with high residential mobility and short occupational periods of small social units (Binford 1990; Smith 2003).

\section{The Interpretation of Activity Areas and Hearth Distribution}

Three distinctive activity areas were defined based on the location of shell middens, features and the distribution of material remains (Figure 6). The activity areas enclose semicircular spaces bounded by shell middens and hearths in characteristic "clean" shallow depressions, which yielded only dispersed lithic material. The central position of these clean areas suggests that activities most likely took place within them, while shell refuse accumulation and most burning took place on the periphery. Material remains and the 
distribution of features suggest activities including food preparation; lithic reduction, use and discard; and possibly the drying of machas.

Activity area A to the NE of the site covers $\sim 90 \mathrm{~m}^{2}$ and is the largest. It is bounded by six shell middens (\#1-6), which form a semicircle oriented towards the south. Adjacent to shell midden \#1, the remains of a hearth (\#II) were recorded. Additionally, beneath shell midden \#6, a small hearth (\#III) was observed. Stratigraphic superposition of the shell middens and hearths suggest that this area formed over different independent events in time. Shell middens \#2 and \#5, as well as hearth \#III, appear at the base of the sequence. Shell midden \#3 lays on top of shell middens \#2 and \#5, and shell midden \#4 rests on top of all three. One shell sample from shell midden \#4 yielded a radiocarbon date of $3560 \pm 35$ BP (OS-63180; marine shell; $\delta^{13} \mathrm{C}=1.3 \%$ ) (Carré et al. 2016). It provides a calibrated age of 2950-3530 cal BP that postdates the initial depositional events, although given the discreet nature of these middens, this temporal difference is not necessarily large. Two additional hearths, \#IV and \#V, occur to the NE of this area at 2.5 and $4 \mathrm{~m}$ from the shell middens, respectively. The conjunction of features (i.e., hearths, middens, and the distinctive surface), the higher frequency and the density of material remains suggest that this was the most utilized area in the site. At least three of the shell middens show combustion activities suggestive of food preparation as indicated by dispersed charcoal particles and the presence of occasional fire marks on shells and bones. This activity area also yielded lithic material, including debitage, bifacial tools, scrapers, milling stones, bored pebbles and fishing weights, among other artifacts.

Activity area B extends over $\sim 74 \mathrm{~m}^{2}$ and is surrounded by four shell middens (\#710). Only hearth \#VI was recorded between shell middens \#8 and 9. Flanked by shell middens \#9 and \#10, excavations revealed an isolated flaking area of a single nodule that 
produced a core and some conjoining flakes, including one that was marginally retouched into a scraper. Conjoining of lithic materials is indicative of a high-resolution brief-span context with a low incidence of postdepositional alterations. This activity area, although containing less material than area A, yielded retouched artifacts, milling stones, flaked pebbles and dispersed lithic debitage as well.

Activity area $\mathrm{C}$ is located at the southern part of the site and is bounded by four shell middens (\#11-14), one of which is a few meters distant from the rest. The three closest shell middens (\#11-13) enclose an area of $\sim 75 \mathrm{~m}^{2}$. Shell middens also form a semicircle oriented towards the SW. Lithic remains are minorly represented, only by fractured pebbles, flakes and debitage. A charcoal sample from shell midden \#11 yielded a radiocarbon date of $3090 \pm 40 \mathrm{BP}\left(\mathrm{OS}-60569\right.$; charcoal; $\delta^{13} \mathrm{C}=-25.3 \%$; $3140-3370$ cal $\mathrm{BP}$ ) (Carré et al. 2016). Six meters SE of this area, five hearths (\#VII-XI) were recorded in a curved pattern. These were located at an equivalent distance to the $\mathrm{S}$ of area $\mathrm{B}$. The closeness of these hearths to each other and to the activity areas strongly suggests a functional association. Additionally, their depth and stratigraphic position indicate a relative contemporaneity between them and the activity areas.

Small open-air hearths with no major associations are difficult to interpret. However, their location along the periphery of the site, their relative closeness to each other and to the activity areas where preferentially machas were processed, as well as the absence/low frequency of other remains, suggest that hearths may have been used to smoke-dry the mollusks. This would have augmented their preservation for delayed consumption, a practice known ethnographically for numerous hunters-gatherer-fishers in the Americas (Waselkov 1987). It is important to mention that drying for delayed consumption of the machas has been documented in different regions along the Pacific 
coast of Peru and Chile (Sandweiss et al. 1999). This bivalve is boiled and/or dried, either hanged or extended and transported in lightweight containers to be consumed afterwards (Daniel Sandweiss personal communication 2019). In the area of Camaná (southernmost Peru), modern data indicates this process was seasonal, involved minimal technology for processing and carrying and was performed by nonspecialists, including nonlocal gatherers, who were able to obtain up to a daily yield of $50 \mathrm{~kg}$ per person (Masuda 1981).

\section{Discussion}

A hollow depression between dunes that provided wind protection and circumscribed space was selected as the area for the campsite. Mainly domestic activities took place at Dunas de Agua Amarilla (LV 007). These included mollusk processing, food preparation of these and other coastal produce, as well as lithic reduction, use and discard. The general low frequency of material evidence indicates low-intensity activities that most likely occurred during a brief period. These occurred around a dwelling area, suggesting the residential character of the site. Dates on marine shell from shell midden \#4 (2950-3530 cal BP) in area A and from charcoal shell midden \#11 (3140-3370 cal BP) in area C provide overlapping calibrated age intervals (either $1 \sigma$ or $2 \sigma$ ). These are close in range to a less precise thermoluminescence age on a fire-cracked rock from the proposed dwelling space. Thus, the age distribution is suggestive of a single occupation. However, the stratigraphic superposition of shell middens and other features is consistent with some degree of site redundancy, although we regard it as minor. Area A was the most intensively and 
redundantly used and seems to have been the foundational point from which later occupations structured campsite organization. No superposition of middens and hearths was recorded in areas $\mathrm{B}$ and $\mathrm{C}$.

At Dunas de Agua Amarilla (LV 007), midden formation implied the intensive collection of machas with a frequency of $>81 \%$. The total estimate of Mesodesma donacium based on the excavated samples is c. 8,200 specimens. This preference attests to this species' great abundance, density, and predictability on the sandy beach located $1.2 \mathrm{~km}$ from the site, the most likely candidate for gathering. Despite having low biomass and low protein content per individual, its insubstantial contribution was compensated by its abundance and low collection costs, even with the possibility of being acquired by gatherers of different age segments. A few harvest days may have provided important quantities of this mollusk, which is consistent with the processing of unique resources typically involved in short stays (Smith 2003). Each midden was possibly the result of a unique collection event. If this was the case, then the number of shell middens could indicate an approximate number of days for site occupation, although it is likely that more than one shell midden could have been formed per day, depending on the number of collectors involved in the harvest. Considering that, along with the limited evidence for other foods (fish $=$ seven individuals; guanaco $=1$ part of one individual) and low abundance of lithic artifacts, it can be suggested that the occupation may have lasted only a few days.

The presence of other gastropods, echinoderms and crustaceans suggests a relatively minor contribution of gathering on intertidal rocky shores, possibly during low tides, while the small mussel Perumytilus purpuratus are often a byproduct of algae collection. However, other small gastropods (e.g., Tegula tridentata, Prisogaster niger, Diloma 
nigerrina and Acanthina monodon) require individual extraction, thus suggesting nonoptimal targets. The high frequencies of Diloma nigerrina $(10.33 \%)$ in shell midden \#4 and of Acanthina monodon (46.16\%) in shell midden \#8 are noteworthy. Such choices suggest the active presence of children in gathering activities, as has been proposed for other archeological contexts in the region, as well as based on ethnoarcheological data from Australian coastal groups (Bird and Bliege Bird 2000; Méndez and Jackson 2004; Méndez and Nuevo-Delaunay 2020).

The presence of small, simple hearths, lacking any structure or distinctive association with food or other material remains and located towards the periphery of the site and close to the activity areas, suggest a functional association with the latter. Based on the mollusk selection preferences, we suggest that such hearths may have been used for smoke-drying machas, given their potential for short-term storage (Smith 2003). Dried machas may have been carried in lightweight containers out of the campsite, allowing a surplus to buffer the contingency of unstable resources in areas distant from the coast where less predictable resources were expected. Other sites in the area with preferential selection of machas are Punta Penitente (LV 014), Quebrada Lazareto (LV 089) and Pichidangui (LV 531, LV 533) (Ballester et al. 2012; Jackson et al. 2005; Méndez 2002). These are all single-species (Mesodesma donacium) middens with ages between 9700 and 8300 cal BP, yet none have been observed in association with dwelling structures or hearths (Méndez and Nuevo-Delaunay 2020). However, south of the dune system, a field processing site at Punta Chungo (LV 039) and a residential site at Fundo de Agua Amarilla (LV 099b), yielded frequencies of machas exceeding $93 \%$ of the molluscan assemblages in an overlapping range between 520 and 230 cal BP (Massone and Jackson 1994; Troncoso et al. 2009). In this case, the contexts suggest intensified gathering for transporting dried 
coastal resources inland where a much more stable settlement has been suggested (Méndez and Nuevo-Delaunay 2020; Seguel et al. 1994).

In the case of Dunas de Agua Amarilla (LV 007), the dwelling space is represented by the subtle traces of a slightly excavated semicircular floor, most likely made of perishable materials. One additional 7,500 cal BP site within the dune system (LV 166) also shows areas free of residue bounded by shell middens and was earlier interpreted as a residential site with a central dwelling space (Jackson, 2004). Lightweight tents or windbreaks are expected for hunter-gatherers with high residential mobility in brief-span occupations, where the energy invested, and the costs of maintenance are minimum (Binford 1990; McGuire and Schiffer 1983; Smith 2003). The small size for the proposed dwelling implies a small number of site occupants, most likely a family unit.

The evidence from other sites dated between 5300-2300 cal BP on the coast of Los Vilos supports a highly mobile residential pattern preferentially along the coast (Méndez and Jackson 2004, 2006; Méndez and Nuevo-Delaunay 2020). Among these sites, eight are dated shell middens where marine invertebrates constitute a principal sedimentary particle in thick and dense charcoal-rich middens where their processing is observed alongside hearth features, fire-cracked rocks, lithic and bone material (Jackson et al. 2004; Jackson and Méndez 2005; Méndez 2002). These highly diverse malacological assemblages show fragmented and burnt evidence as result of intrasite activities and possible trampling (Méndez and Jackson 2004). The Dunas de Agua Amarilla site (LV 007) is different from these dense middens and adds variability to the archeological record of the period between 5300-2300 cal BP. As a small camp with ephemeral architecture located further away from the coastline, its faunal evidence indicates the transport of specific resources from procurement locations. The spatial distribution of the shell middens and features reveal a 
spatial organization otherwise unseen at sites of the same age. As such, this site may be considered as a logistical camp where key resources were processed; in this case, dried for delayed consumption (Binford 1980:8). This variability is expected for a period in which higher archeological deposition suggests a more sustained human presence along the coast (Méndez and Nuevo-Delaunay 2020). Additionally, the interpretation of mollusks being processed for delayed consumption has not been suggested for other contemporaneous sites in the area and further implies that resources were transported elsewhere, most likely inland. This agrees with current radiocarbon evidence suggesting an increase in records of human occupation in the El Mauro valley, $45 \mathrm{~km}$ inland, at c. $3000 \mathrm{cal}$ BP (Gómez and Pacheco 2016; López-Mendoza et al. 2016). In this way, given the predictability of resources in coastal environments, these may have provided a buffer during relatively dry periods, such as between 3800 and 2700 cal BP when regional climate variability produced stress on resources (Maldonado and Villagrán 2002, 2006).

\section{Conclusion}

The Dunas de Agua Amarilla (LV 007) site may be defined as a small brief-span residential campsite, as indicated by the limited diversity of activities conducted within it and by the small accumulation of refuse over few repeated occupational events. Targeting almost one single, easy-to-obtain, invertebrate resource such as the macha, available within $1.2 \mathrm{~km}$ of the settlement, underscores the knowledge of the distribution and predictability of marine resources by populations long adapted to this coast. Campsites between 5300- 
$2300 \mathrm{cal}$ BP in the area were characterized by brief occupational events framed within a littoral residential mobility in which predictable coastal resources became a staple for groups residing over long periods in the area (Méndez and Nuevo-Delaunay 2020).

Shell middens, especially those with few cultural remains, may be uncritically seen as mere processing areas (Gamble 2017). However, detailed excavations may provide evidence revealing a more complex picture where the distribution of features, degrees of redundancy and diversity of activities, or lack of, may be informative of the characteristics of site planning. In this sense, shell middens, as well as other small features, may indicate a structural and functional complexity that cannot be reduced to considering them only as refuse dumps resulting from the exploitation of marine resources. As such, they have the potential to reveal meaningful associations that may be informative of hunter-gatherer site planning and decision making.

Acknowledgments. Funded by the National Geographic Society grant \#8122-06, FONDECYT \#1170408, and Programa CONICYT Regional R17A10002. Donald Jackson conducted the excavation, planned the methodology and provided an initial interpretation of the site context alongside an early version of the manuscript. We are enormously indebted to his contribution to this study. We acknowledge Daniel Sandweiss for his observations on macha gathering and processing, Fernanda Falabella for providing us with the modern shell sample from Pullalli, Jimena Torres for taxonomical determinations of fish, Canek Jackson for mollusk quantification, César Miranda and Gregorio Calvo for field assistance, and Paulina Chávez for help with some of the figures and Amalia Nuevo Delaunay for her help in various stages of this paper. 
Data Availability Statement.

All specimens in this study are curated in the Anthropology Department, Universidad de Chile (address Capitán Ignacio Carrera Pinto 1045, Nuñoa, Santiago, 7800284, Chile). They are available prior consultation to the collection curator:

(http://www.facso.uchile.cl/antropologia/patrimonio/55923/colecciones-de-antropologia).

Supplementary Materials. For supplementary material accompanying this paper, visit www.journals.cambridge.org/[Journal]

Supplementary figure 1: Context images of the excavations at Dunas de Agua Amarilla (LV 007); (a) shell midden distribution; (b) location of the excavations (northern trench); (c) excavation of unit 2; (d) excavation of unit 3.

Supplementary table 1: Absolute frequency of mollusk remains (MNI) from sampled shell middens (SM) and the percentage of Mesodesma donacium in each sample.

Supplementary table 2: NISP and MNI for fish remains recorded at Dunas de Agua Amarilla (LV 007). 


\section{References Cited}

Ballester, Benjamin, Donald Jackson, Matthiu Carré, Antonio Maldonado, César Méndez, and Roxana Seguel

2012 An early Holocene Task Camp ( $8.5 \mathrm{ka}$ cal BP) on the Coast of the SemiArid North of Chile. Antiquity 86(331):88-98.

Binford, Lewis R.

1980 Willow Smoke and Dogs' Tails: Hunter-Gatherer Settlement Systems and Archaeological Site Formation. American Antiquity 45(1):4-20.

Binford, Lewis R.

1990 Mobility, Housing, and Environment: A Comparative Study. Journal of Anthropological Research 46(2):119-152.

Bird, Douglas W., and Rebecca Bliege Bird

2000 The Ethnoarchaeology of Juvenile Foragers: Shellfishing Strategies Among Meriam Children. Journal of Anthropological Archaeology 19:461-476.

Carré, Matthieu, Ilhem Bentaleb, Dominique Blamart, Neil Ogle, Freddy Cardenas, Sheyla Zevallos, Robert M. Kalin, Luc Ortlieb, and Michel Fontugne 2005 Stable Isotopes and Sclerochronology of the Bivalve Mesodesma donacium: Potential Application to Peruvian Paleoceanographic Reconstructions. Palaeogeography, Palaeoclimatology, Palaeoecology 228(1):4-25. 
Carré, Matthieu, Donald Jackson, Antonio Maldonado, Brian M. Chase, and Julian P. Sachs 2016 Variability of 14C Reservoir Age and Air-Sea Flux of $\mathrm{CO}_{2}$ in the PeruChile Upwelling Region During the Past 12,000 Years. Quaternary Research 85(1):87-93.

Claassen, Cheryl

1998 Shells (Cambridge Manuals in Archaeology). Cambridge University Press, Cambridge.

DeBlasis, Paulo, Andreas Kneip, Rita Scheel-Ybert, Paulo Giannini, and Maria Dulce Gaspar

2007 Sambaquis e Paisagem. Dinâmica Natural e Arqueologia Regional no Litoral do sul do Brasil. Arqueologia Sudamericana/Arqueologia Sul-americana 3(1):2661.

Erlandson, Jon, and Madonna Moss 2001 Shellfish Feeders, Carrion Eaters, and the Archaeology of Aquatic Adaptations. American Antiquity 66:413-432.

Favier Dubois, Cristian M. and Florencia Borella 2007. Consideraciones acerca de los procesos de formación de concheros de la costa norte del Golfo San Matías, Río Negro. Cazadores Recolectores del Cono Sur 2:151-165. 
Gamble, Lynn H.

2017 Feasting, Ritual Practices, Social Memory, and Persistent Places: New Interpretations of Shell Mounds in Southern California. American Antiquity 82:427451.

Garreaud, René D., Mathias Vuille, Rosa Compagnucci, and José Marengo

2009 Present-Day South American Climate. Palaeogeography, Palaeoclimatology, Palaeoecology 281(3):180-195.

Gómez, Pablo, and Aryel Pacheco

2016 Movilidad y Dieta en el Valle de El Mauro (31 $57^{\prime}$ S. - $71^{\circ} 01^{\prime}$ W.), Norte Semiárido de Chile, entre 8350-929 cal. AP. Comechingonia 20(1):51-79.

Hogg, Alan G., Quan Hua, Paul G. Blackwell, Mu Niu, Caitlin E. Buck, Thomas P. Guilderson, Timothy J. Heaton, Jonathan G. Palmer, Paula J. Reimer, Ron W. Reimer, Christian S. M. Turney, and Susan R. H. Zimmerman 2013 SHCal13 Southern Hemisphere Calibration, 0-50,000 Years cal BP. Radiocarbon 55:1889-1903.

Jackson, Donald, 2004 Los Implementos de Molienda en un Campamento Estacional del Holoceno Medio: Implicancias Funcionales y Contextuales. Chungara Revista de Antropología Chilena 36(número especial 1):95-103 
Jackson, Donald, Pedro Báez, and Javier Arata

2004 Composición de Conchales, Estrategia de Subsistencia y Cambios

Paleoambientales en un Asentamiento Arcaico, Norte Chico de Chile. Boletín de la Sociedad Chilena de Arqueología 37:37-48.

Jackson, Donald, Pedro Báez, and Loreto Vargas

1995 Secuencia Ocupacional y Adaptaciones Durante el Arcaico en la Comuna de Los Vilos, Provincia de Choapa. Proceedings of the XIII Congreso Nacional de Arqueología Chilena, 99-114, Antofagasta, Chile.

Jackson, Donald, and César Méndez

2005 Reocupando el Espacio: Historia de un Asentamiento Multicomponente, Sus Relaciones Inter-Sitios y los Cambios Paleoambientales de la Costa del Choapa. Werken 6:97-112.

Jackson, Donald, César Méndez, Patricio López, Douglas Jackson, and Roxana Seguel 2005 Evaluación de un Asentamiento Arqueológico en el Semiárido de Chile: Procesos de Formación, Fauna Extinta y Componentes Culturales. Intersecciones en Antropología 6:139-151.

Jerardino, Antonieta

1997 Changes in Shellfish Species Composition and Mean Shell Size from a LateHolocene Record of the West Coast of Southern Africa. Journal of Archaeological Science 24:1031-1044. 
Jerardino, Antonieta

2016 Shell Density as Proxy for Reconstructing Prehistoric Aquatic Resource Exploitation and Transport, Perspectives from southern Africa. Journal of Archaeological Science: Reports 6:637-644.

Koike, Hiroko

1986 Prehistoric Hunting Pressure and Paleobiomass: An Enviromental Reconstruction and Archaeozoological Analysis of a Jomon Shellmound Area. In Prehistoric Hunter Gatherers in Japan: New Research Methods, edited by Takeru Akazawa and Melvin C. Aikens, pp. 27-53. University of Tokyo, Tokyo.

Lavallée, Danièle and Michèle Julien

2012 Prehistoria de la Costa Extremo-Sur del Perú. Los Pescadores Arcaicos de la Quebrada de los Burros (10000 - 7000 a.P.). Instituto Francés de Estudios Andinos and Fondo Editorial de la Pontificia Universidad Católica del Perú, Lima, Perú.

López-Mendoza, Patricio, Isabel Cartajena, Boris Santander, Daniela Villalón, Alina Sáez, and Bárbara Rivera

2016 Procesamiento de Guanacos Durante el Arcaico Tardío del Norte Semiárido de Chile: Un Acercamiento Zooarqueológico y Espacial Intrasitio. Chungara Revista de Antropología Chilena 48:243-258. 
Luebert, Federico, and Patricio Pliscoff

2006 Sinopsis Bioclimática y Vegetacional de Chile. Editorial Universitaria, Santiago, Chile.

Maldonado, Antonio, María Eugenia De Porras, Andrés Zamora, Marcelo Rivadeneira, and Ana María Abarzúa

2016 El Escenario Geográfico y Paleoambiental de Chile. In Prehistoria en Chile. Desde sus Primeros Habitantes hasta los Incas, edited by Fernanda Falabella, Mauricio Uribe, Lorena Sanhueza, Carlos Aldunate, and Jorge Hidalgo, pp. 23-70. Editorial Universitara, Santiago, Chile.

Maldonado, Antonio, César Méndez, Paula Ugalde, Donald Jackson, Roxana Seguel, and Claudio Latorre 2010 Early Holocene Climate Change and Human Occupation Along the Semiarid Coast of North-Central Chile. Journal of Quaternary Science 25:985-988.

Maldonado, Antonio, and Carolina Villagrán 2002 Paleoenvironmental Changes in the Semiarid Coast of Chile $\left(\sim 32^{\circ} \mathrm{S}\right)$ During the Last 6200 cal Years Inferred from a Swamp-Forest Pollen Record. Quaternary Research 58(2):130-138.

Maldonado, Antonio, and Carolina Villagrán 
2006 Climate Variability Over the Last 9900 cal yr BP from a Swamp Forest Pollen Record Along the Semiarid Coast of Chile. Quaternary Research 66:246258.

Mason, Roger D., Mark L. Peterson, and Joseph A. Tiffany 1998 Weighing vs. Counting: Measurement Reliability and the California School of Midden Analysis. American Antiquity 63:303-324.

Massone, Mauricio, and Donald Jackson 1994 Asentamiento de Explotación Litoral del Agroalfarero Medio-Tardío en la Comuna de Los Vilos, Provincia de Choapa. Boletín del Museo Regional de la Araucanía 5:9-18.

Masuda, Shozo 1981 Cochayuyo, Macha, Camarón y Higos Charqueados. In Estudios Etnográficos del Perú Meridional, edited by Shozo Mazuda, pp. 173-192. University of Tokyo, Tokyo.

McGuire, Randall H., and Michael B. Schiffer 1983 A Theory of Architectural Design. Journal of Anthropological Archaeology $2: 277-303$.

Méndez, César 
2002 Cazadores Recolectores Costeros y sus Contextos de Tarea: Una Visión Desde el Asentamiento Holocénico Temprano de Punta Penitente (L.V.014), Los Vilos. Chungara Revista de Antropología Chilena 34(2):153-166.

Méndez, César, and Donald Jackson

2004 Ocupaciones Humanas del Holoceno Tardío en Los Vilos (IV Región, Chile): Origen y Características Conductuales de la Población Local de Cazadores Recolectores de Litoral. Chungara Revista de Antropología Chilena 36:279-293.

Méndez, César, and Donald Jackson

2006 Causalidad o Concurrencia, Relaciones Entre Cambios Ambientales y Sociales en los Cazadores Recolectores Durante la Transición Entre el Holoceno Medio y Tardío (Costa del Semiárido de Chile). Chungara Revista de Antropología Chilena 38(2):169-180.

Méndez, César, and Amalia Nuevo-Delaunay 2020 The Long-Term Relation between Human Beings and Shellfish in the Semiarid Coast of Chile. In South American Contributions to World Archaeology, edited by Mariano Bonomo and Sonia Archila, In press. Springer.

Méndez, César, Roxana Seguel, Amalia Nuevo-Delaunay, Ismael Murillo, Patricio López Mendoza, Douglas Jackson, and Antonio Maldonado 2019 Depositional Contexts and New Age Controls for Terminal Pleistocene Megafauna in North Central Chile (31 $50^{\circ}$ 'S). PaleoAmerica. in press. 
Montecinos, Aldo, and Patricio Aceituno

2003 Seasonality of the ENSO-Related Rainfall Variability in Central Chile and Associated Circulation Anomalies. Journal of Climate 16:281-296.

Niemeyer, Hans, and Virgilio Schiappacasse

1969 Análisis Cuantitativo de un Sitio Habitacional. Sitio El Pimiento, Provincia. de Coquimbo. Proceedings of the V Congreso Nacional de Arqueología Chilena, 207-220, La Serena, Chile.

Ortega, Cristina, Gabriel Vargas, José A. Rutllant, Donald Jackson, and César Méndez 2012 Major Hydrological Regime Change Along the Semiarid Western Coast of South America During the Early Holocene. Quaternary Research 78:513-527.

Rein, Bert, Andreas Lückge, Lutz Reinhardt, Frank Sirocko, Anja Wolf, and WolfChristian Dullo 2005 El Niño Variability off Peru during the last 20,000 years. Paleoceanography 20:PA4003.

Sandweiss, Daniel H.

1996 Environmental Change and its Consequences for Human Society on the Central Andean Coast: A Malacological Perspective. In Case Studies in Environmental Archaeology, edited by Elizabeth J. Reitz, Lee A. Newsom, and Sylvia J. Scudder, pp. 127-146. Plenum Press, New York, NY. 
Sandweiss, Daniel H., Asunción Cano, Bernardino Ojeda, and José Roque 1999 Pescadores Paleoíndios del Perú. Investigación y Ciencia 277:2-8.

Sandweiss, Daniel H., Heather McInnis, Richard L. Burger, Asunción Cano, Bernardino Ojeda, Rolando Paredes, María del Carmen Sandweiss, and Michael D. Glascock 1998 Quebrada Jaguay: Early South American Maritime Adaptations. Science 281:1830.

Seguel, Roxana, Donald Jackson, Arturo Rodríguez, Pedro Báez, Ximena Novoa, and Mario Henríquez

1994 Rescate de un Asentamiento Diaguita Costero: Proposición de una Estrategia de Investigación y Conservación. Boletín del Centro de Investigación Diego Barros Arana 3:34-42.

Smith, Craig S.

2003 Hunter-Gatherer Mobility, Storage, and Houses in a Marginal Environment: An Example from the Mid-Holocene of Wyoming. Journal of Anthropological Archaeology 22:162-189.

Stein, Julie K.

1992 Deciphering a Shell Midden. Academic Press, San Diego, CA.

Stuiver, Minze, Paula J. Reimer, and Ron W. Reimer 
2018 CALIB 7.4 [WWW program].

Thompson, Victor D., William H. Marquardt, Alexander Cherkinsky, Amanda D.

Thompson, Karen J. Walker, Lee A. Newsom, and Michael Savarese

2016 From Shell Midden to Midden-Mound: The Geoarchaeology of Mound Key, an Anthropogenic Island in Southwest Florida, USA. PLoS One 11:e154611.

Troncoso, Andrés, Cristian Becker, Daniel Pavloviv, Paola González, Jorge Rodríguez, and Claudia Solervicens

2009 El Sitio LV099-b "Fundo Agua Amarilla" y la Ocupación del Período

Incaico en la Costa de la Provincia del Choapa, Chile. Chungara Revista de Antropología Chilena 41:241-259.

Waselkov, Gregory A.

1987 Shellfish Gathering and Shell Midden Archaeology. Advances in Archaeological Method and Theory 10:93-210. 


\section{Figure Captions}

Figure 1. Map of (a) western South America and (b) the study area with the location of Dunas de Agua Amarilla (LV 007) and other sites mentioned in the paper.

Figure 2. Images of Dunas de Agua Amarilla (LV 007) site; (a) oblique view of the depression bounding the site (scale 60 m, Google Earth, 2012 image); (b) general view of the site and the Malpaso ravine to the south; (c) general view of the site and the Pacific ocean (Agua Amarilla beach) to the west; (d) intersection between two excavated trenches; (e) example of one of the excavated hearths.

Figure 3. Values of $\delta^{18} \mathrm{O}$ from modern Mesodesma donacium shell samples from La Serena $\left(30^{\circ} \mathrm{S}\right.$; black triangles $)$, Pullalli $\left(33^{\circ} \mathrm{S}\right.$, black squares) and the archaeological samples from shell middens (SM) from LV 007 at Los Vilos (3151' S; white squares).

Figure 4. Mollusk taxa frequency (grouped) by sampled shell midden (SM) at Dunas de Agua Amarilla (LV 007).

Figure 5. Excavated cross-sections of trench \#4, (a) north profile showing distinctive buried surface and location of findings, (b) west profile showing distinctive buried surface and post mold feature. 
Figure 6. Interpreted site plan of Dunas de Agua Amarilla (LV 007). 


\section{List of Tables}

Table 1. Excavated units, dimensions and main associated archaeological record at Dunas de Agua Amarilla (LV 007).

Table 2. Formal characteristics of the shell middens at Dunas de Agua Amarilla (LV 007).

Table 3. Formal characteristics of hearths and their associations at Dunas de Agua Amarilla (LV 007). 
Table 1. Excavated units, dimensions and main associated archaeological record at Dunas de Agua Amarilla (LV 007).

\begin{tabular}{|c|c|c|c|}
\hline Trench \# & Dimensions & Maximum depth & Archaeological evidence \\
\hline 1 & $10 \times 1 \mathrm{~m}\left(10 \mathrm{~m}^{2}\right)$ & $110 \mathrm{~cm}$ & Absent \\
\hline 2 & $11 \times 2 \mathrm{~m}\left(22 \mathrm{~m}^{2}\right)$ & $140 \mathrm{~cm}$ & Hearths $(\mathrm{N}=5)$ \\
\hline 3 & $5 \times 1 \mathrm{~m}\left(5 \mathrm{~m}^{2}\right)$ & $70 \mathrm{~cm}$ & Absent \\
\hline 4 & $10 \times 1 \mathrm{~m}\left(10 \mathrm{~m}^{2}\right)$ & $85 \mathrm{~cm}$ & Distinctive surface and hearth $(\mathrm{N}=1)$ \\
\hline 5 & $6 \times 2 \mathrm{~m}\left(12 \mathrm{~m}^{2}\right)$ & $60 \mathrm{~cm}$ & Absent \\
\hline 6 & $5 \times 1 \mathrm{~m}\left(5 \mathrm{~m}^{2}\right)$ & $40 \mathrm{~cm}$ & Hearths $(\mathrm{N}=5)$ \\
\hline 7 & $8 \times 1 \mathrm{~m}\left(8 \mathrm{~m}^{2}\right)$ & $80 \mathrm{~cm}$ & Absent \\
\hline 8 & $4 \times 2 \mathrm{~m}\left(8 \mathrm{~m}^{2}\right)$ & $60 \mathrm{~cm}$ & Absent \\
\hline 9 & $3 \times 1 \mathrm{~m}\left(3 \mathrm{~m}^{2}\right)$ & $80 \mathrm{~cm}$ & Lithic material \\
\hline
\end{tabular}


Table 2. Formal characteristics of the shell middens at Dunas de Agua Amarilla (LV 007).

\begin{tabular}{|c|c|c|c|}
\hline Shell midden \# & Diameter (m) & Thickness $(\mathrm{cm})$ & Excavated area $\left(\mathrm{m}^{2}\right)$ \\
\hline 1 & $3.3 \times 3.3$ & 2 & 4 \\
\hline 2 & $2.2 \times 2.2$ & 8 & -- \\
\hline 3 & $2.4 \times 2.4$ & 20 & 1.25 \\
\hline 4 & $2.6 \times 2.2$ & 6 & 2 \\
\hline 5 & $1.3 \times 1.3$ & 8 & 1.7 \\
\hline 6 & $1.2 \times 1.2$ & 2 & 1 \\
\hline 7 & $4.5 \times 4.5$ & 2 & -- \\
\hline 8 & $1.9 \times 1.6$ & 8 & 0.25 \\
\hline 9 & $2.4 \times 1.6$ & 8 & -- \\
\hline 10 & $2.0 \times 1.5$ & 8 & -- \\
\hline 11 & $2.2 \times 1.8$ & 8 & 1 \\
\hline 12 & $2.1 \times 1.7$ & 3 & -- \\
\hline 13 & $4.7 \times 1.9$ & 2 & -- \\
\hline 14 & $2.0 \times 1.5$ & 2 & 1 \\
\hline Average & $2.49 \times 2.05$ & 6.21 & -- \\
\hline $\mathrm{sd}$ & $1,03 \times 0.89$ & 4.87 & -- \\
\hline
\end{tabular}



Table 3. Formal characteristics of hearths and their associations at Dunas de Agua Amarilla (LV 007).

\begin{tabular}{|c|c|c|c|c|}
\hline Hearth \# & Shape & Length and width $(\mathrm{cm})$ & Depth $(\mathrm{cm})$ & Associations \\
\hline I & ND & ND & ND & Distinctive surface \\
\hline II & Irregular & ND & ND & Shell miden \#1 \\
\hline III & Irregular & $75 \times 70$ & 2 & Shells \\
\hline IV & ND & ND & ND & No \\
\hline $\mathrm{V}$ & Oval & $72 \times 30$ & 2 & No \\
\hline VI & Oval & $60 \times 50$ & 7.5 & Shells \\
\hline VII & Oval & $62 \times \mathrm{ND}$ & 3.5 & No \\
\hline VIII & Oval & $54 \times 50$ & 3 & No \\
\hline IX & Circular & $22 \times 22$ & 3 & No \\
\hline $\mathrm{X}$ & Oval & $40 \times 32$ & 4 & No \\
\hline $\mathrm{XI}$ & ND & ND & ND & No \\
\hline Average & -- & $55 \times 42$ & 3.57 & -- \\
\hline
\end{tabular}

Note: ND: no data. 


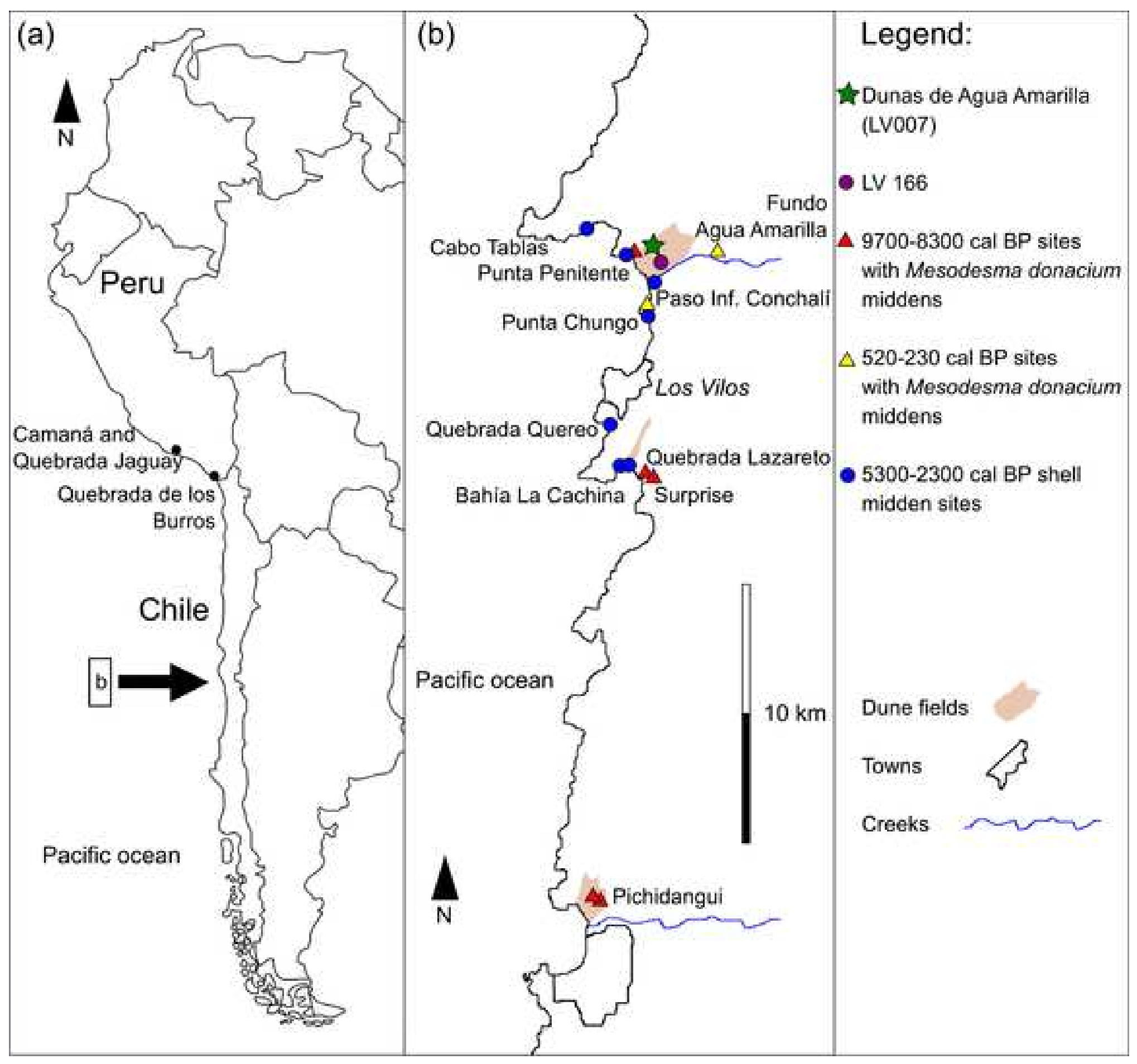




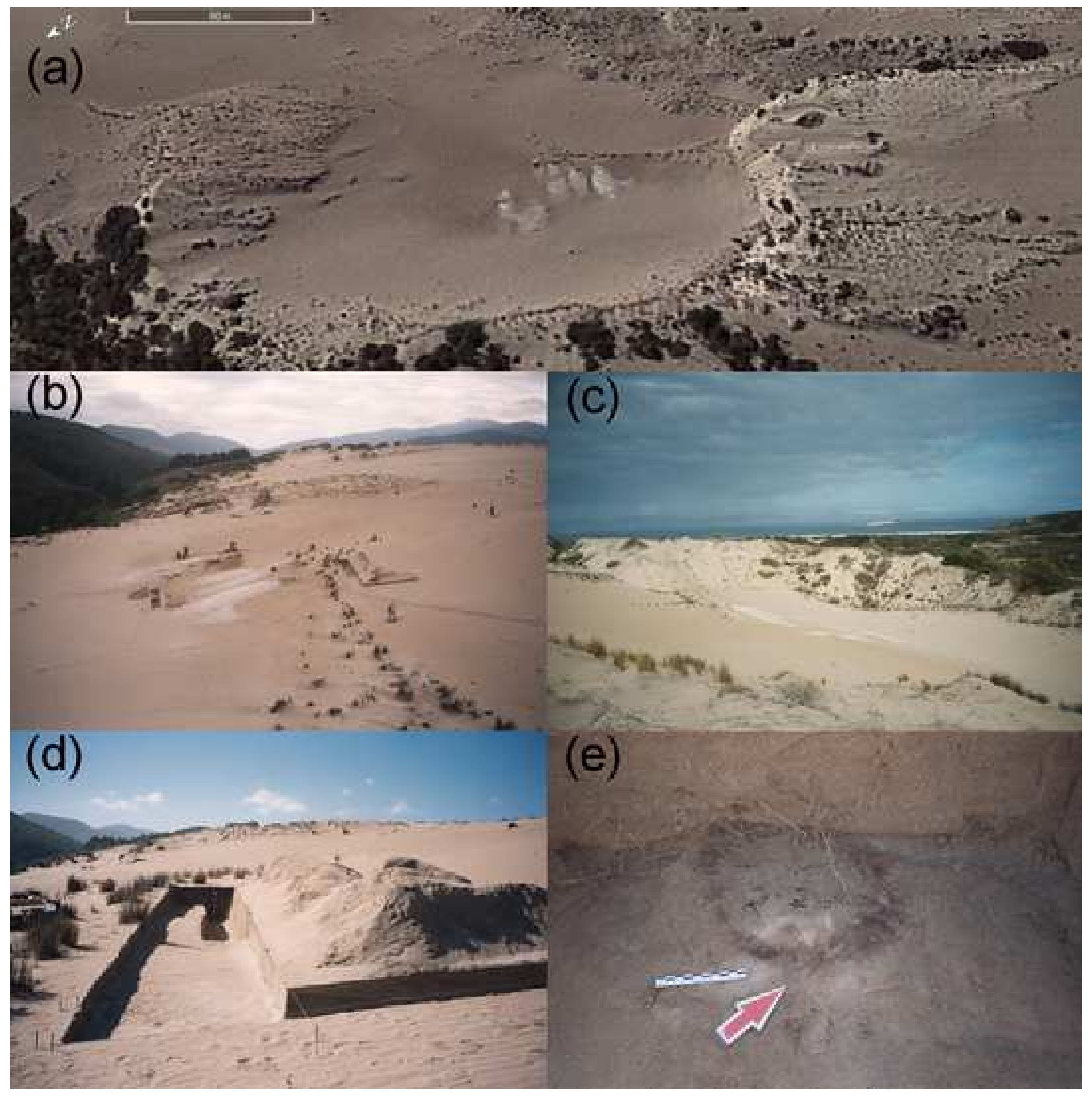




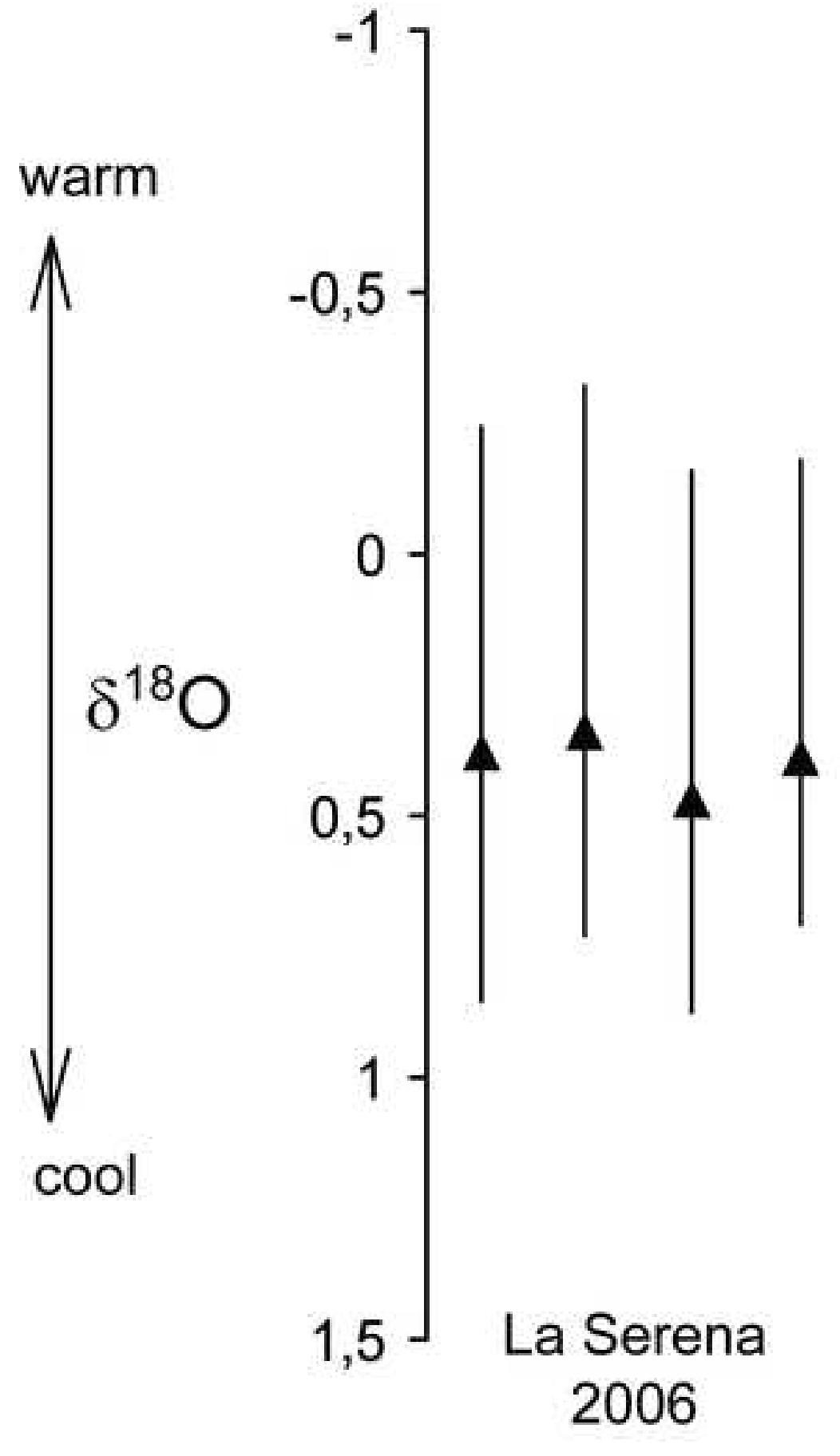

Pullalli 1982-1983

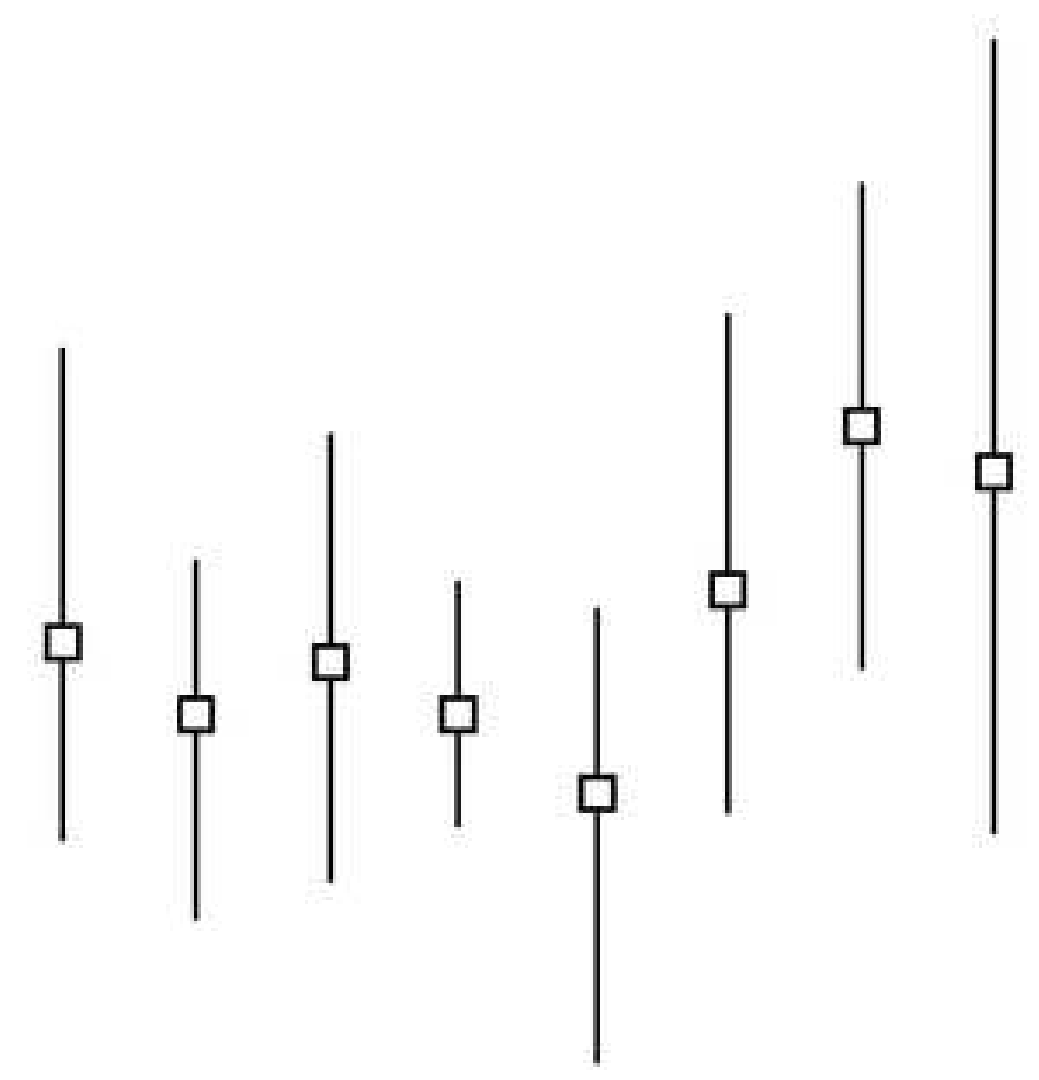

SM \#4
Los Vilos, LV 007 3000-3500 cal BP 


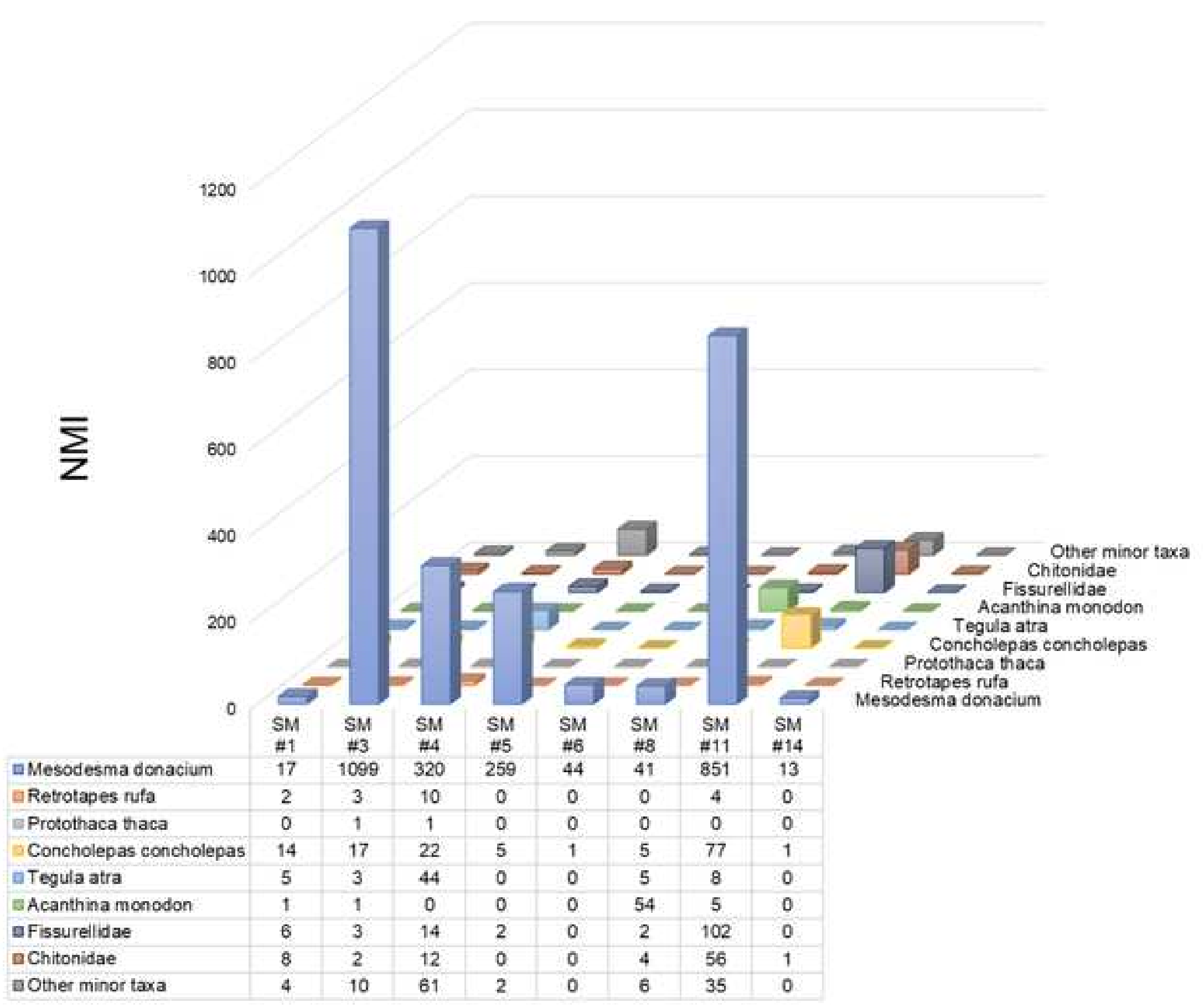


(a)

W

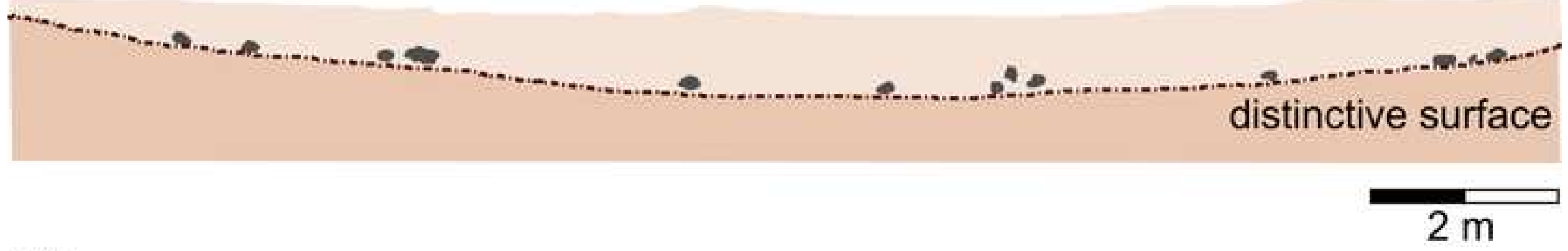

(b)

S

$\mathrm{N}$

- artifacts and fire craked rocks

distinctive surface

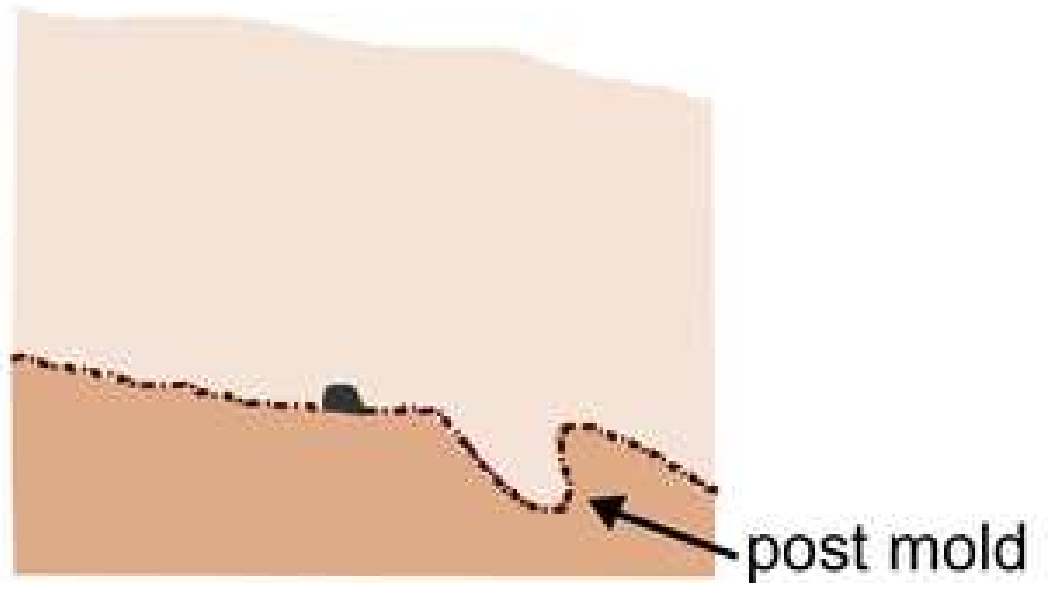

$40 \mathrm{~cm}$ 


\section{\# 1 - 14: shell middens \\ \# I - XI : hearths \\ DS : distinctive surface \\ A-C : activity areas \\ fa : flaking area}

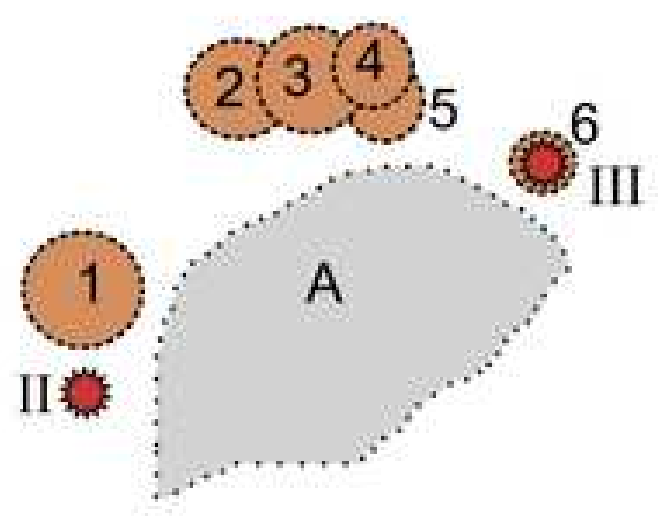

N
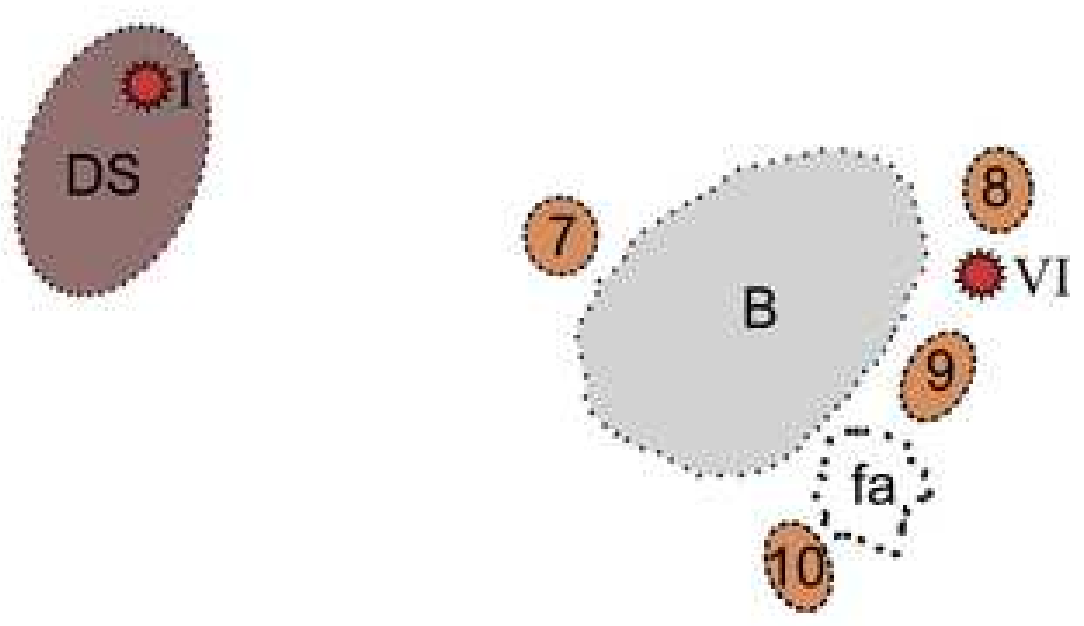

$2 \mathrm{~m}$
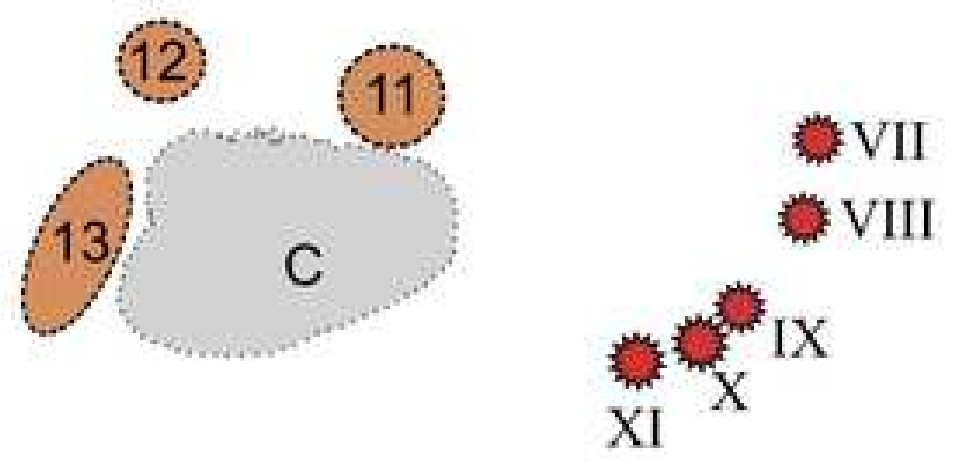
Supplementary figure 1: Context images of the excavations at Dunas de Agua Amarilla (LV 007); (a) shell midden distribution; (b) location of the excavations (northern trench); (c) excavation of unit 2; (d) excavation of unit 3.

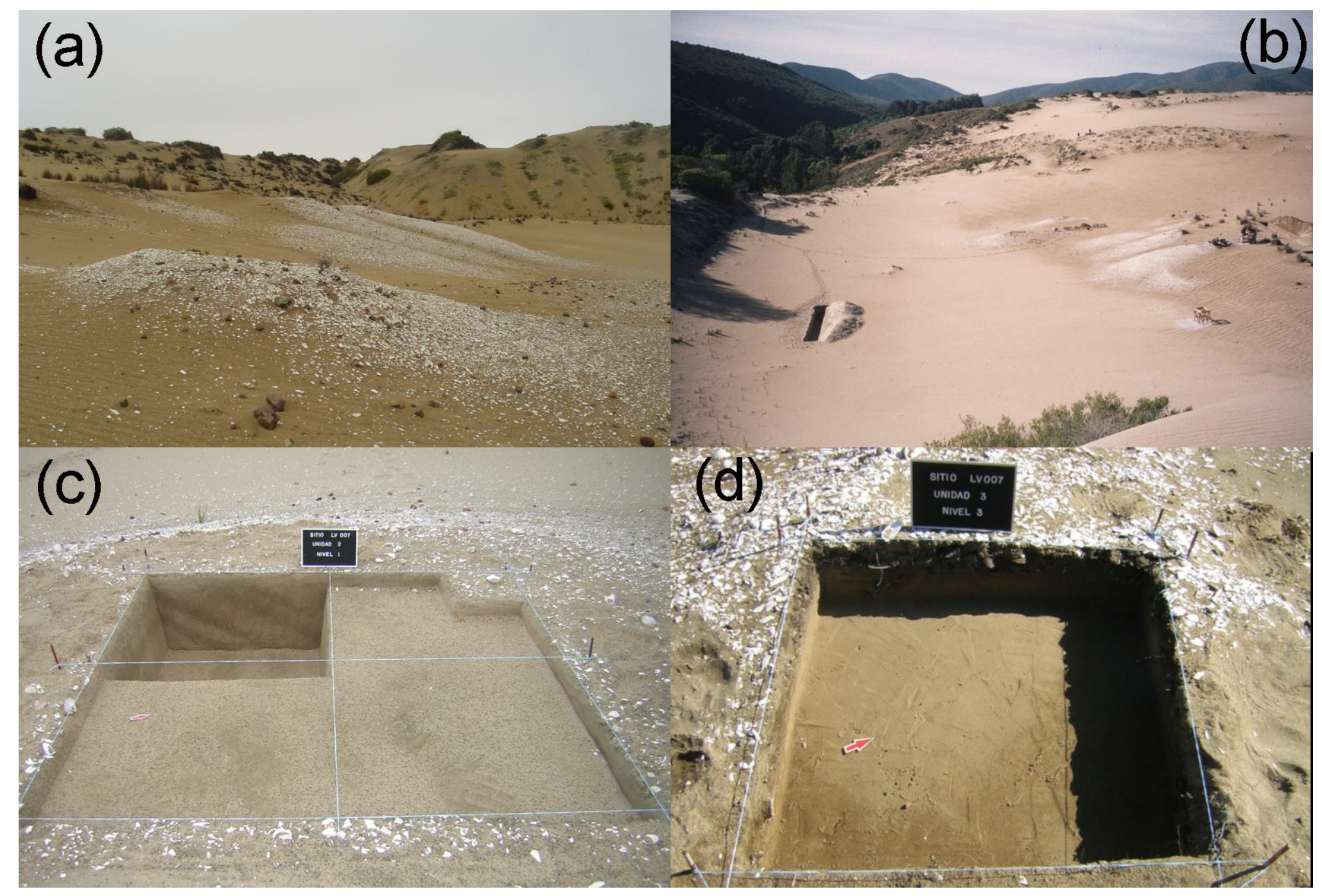


Supplementary table 1: Absolute frequency of mollusk remains (MNI) from sampled shell middens (SM) and the percentage of Mesodesma donacium in each sample.

\begin{tabular}{|c|c|c|c|c|c|c|c|c|}
\hline Таха & SM \#1 & SM \#3 & SM \#4 & SM \#5 & SM \#6 & SM \#8 & SM \#11 & SM \#14 \\
\hline Mesodesma donacium & $\begin{array}{c}17 \\
(29 \%)\end{array}$ & $\begin{array}{c}1099 \\
(96.4 \%)\end{array}$ & $\begin{array}{c}320 \\
(66.1 \%)\end{array}$ & $\begin{array}{c}259 \\
(96.6 \%)\end{array}$ & $\begin{array}{c}44 \\
(97.7)\end{array}$ & $\begin{array}{c}41 \\
(35 \%)\end{array}$ & $\begin{array}{c}851 \\
(94.7 \%)\end{array}$ & $\begin{array}{c}13 \\
(86.6 \%)\end{array}$ \\
\hline Perumytilus purpuratus & 1 & 0 & 0 & 0 & 0 & 0 & 2 & 0 \\
\hline Retrotapes rufa & 2 & 3 & 10 & 0 & 0 & 0 & 4 & 0 \\
\hline Protothaca thaca & 0 & 1 & 1 & 0 & 0 & 0 & 0 & 0 \\
\hline Concholepas concholepas & 14 & 17 & 22 & 5 & 1 & 5 & 77 & 1 \\
\hline Tegula atra & 5 & 3 & 44 & 0 & 0 & 5 & 8 & 0 \\
\hline Tegula tridentata & 0 & 0 & 1 & 0 & 0 & 0 & 0 & 0 \\
\hline Prisogaster niger & 1 & 1 & 2 & 0 & 0 & 1 & 4 & 0 \\
\hline Diloma nigerrima & 1 & 3 & 50 & 1 & 0 & 4 & 5 & 0 \\
\hline Acanthina monodon & 1 & 1 & 0 & 0 & 0 & 54 & 5 & 0 \\
\hline Fissurella crassa & 1 & 2 & 3 & 0 & 0 & 1 & 10 & 0 \\
\hline Fissurella nigra & 1 & 0 & 5 & 2 & 0 & 0 & 21 & 0 \\
\hline Fissurella picta & 1 & 1 & 6 & 0 & 0 & 1 & 43 & 0 \\
\hline Fissurella maxima & 0 & 0 & 0 & 0 & 0 & 0 & 1 & 0 \\
\hline
\end{tabular}




\begin{tabular}{|c|c|c|c|c|c|c|c|c|}
\hline Fissurella latimarginata & 0 & 0 & 0 & 0 & 0 & 0 & 13 & 0 \\
\hline Fissurella costata & 0 & 0 & 0 & 0 & 0 & 0 & 1 & 0 \\
\hline Fissurella sp. & 3 & 0 & 0 & 0 & 0 & 0 & 13 & 0 \\
\hline Acanthopleura echinata & 2 & 2 & 2 & 0 & 0 & 1 & 8 & 0 \\
\hline Chiton granosus & 2 & 0 & 3 & 0 & 0 & 1 & 7 & 0 \\
\hline Chiton latus & 3 & 0 & 3 & 0 & 0 & 1 & 0 & 0 \\
\hline Chiton sp. & 1 & 0 & 4 & 0 & 0 & 1 & 0 & 0 \\
\hline Littorina peruviana & 0 & 0 & 1 & 0 & 0 & 0 & 0 & 0 \\
\hline Oliva peruviana & 0 & 5 & 0 & 1 & 0 & 0 & 0 \\
\hline Scurria parasitica & 1 & 1 & 7 & 0 & 0 & 1 & 24 & 0 \\
\hline Total & 57 & 1139 & 484 & 268 & 45 & 117 & 1138 & 15 \\
\hline $\begin{array}{c}\text { Shannon-Weiner diversity } \\
\text { index }\end{array}$ & 0.9 & 0.1 & 0.56 & 0.08 & 0.05 & 0.61 & 0.47 & 0.21 \\
\hline
\end{tabular}


Supplementary table 2: NISP and MNI for fish remains recorded at Dunas de Agua Amarilla (LV 007).

\begin{tabular}{|c|c|c|c|}
\hline Taxa & Vernacular name & NISP & NMI \\
\hline Sebastes capensis & Cabrilla & 3 & 1 \\
\hline Thirsistes atun & Sierra & 19 & 2 \\
\hline Trachurus symmetricus & Jurel & 2 & 1 \\
\hline Cilus gilberti & Corvina & 3 & 2 \\
\hline Scartichthys viridis & Borrachilla & 1 & 1 \\
\hline Undeterminate & & 100 & - \\
\hline Total & & 128 & 7 \\
\hline
\end{tabular}


October 10, 2019

\section{Editors}

Latin American Antiquity

Dear Editors,

I write to confirm that César Méndez and his colleagues have my permission to use a personal communication from me, regarding Peruvian shell processing, in their paper on "Site Context and the Spatial Organization of a Late Holocene Coastal Hunter-Gatherer Campsite from NorthCentral Chile, South America" to be submitted to your journal.

Sincerely,

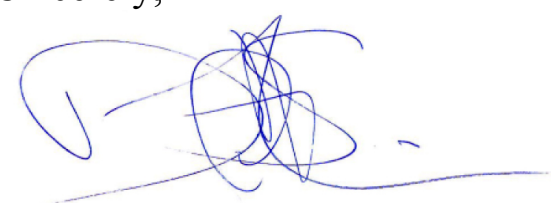

Dan Sandweiss

Professor of Anthropology and Quaternary \& Climate Studies

Rising Tide Professor (2018-2020)

Cooperating Professor of Earth and Climate Sciences and Global Policy 


\section{Editing Certificate}

This document certifies that the manuscript

SITE CONTEXT AND THE SPATIAL ORGANIZATION OF A LATE HOLOCENE COASTAL HUNTER-GATHERER CAMPSITE FROM NORTH-CENTRAL CHILE, SOUTH AMERICA

prepared by the authors

César Méndez, Matthieu Carré, Antonio Maldonado, Roxana Seguel, and Donald Jackson

was edited for proper English language, grammar, punctuation, spelling, and overall style by one or more of the highly qualified native English speaking editors at AJE.

This certificate was issued on October 8, 2019 and may be verifed on the AJE website using the verification code AEOC-C96E-99C7-AC70-A49E .

Neither the research content nor the authors' intentions were altered in any way during the editing process. Documents receiving this certification should be English-ready for publication; however, the author has the ability to accept or reject our suggestions and changes. To verify the final AJE edited version, please visit our verification page at aje.com/certificate.

If you have any questions or concerns about this edited document, please contact AJE at support@aje.com.

AJE provides a range of editing, translation, and manuscript services for researchers and publishers around the world. For more information about our company, services, and partner discounts, please visit aje.com. 